\title{
The angiotensin II type 2 receptor agonist Compound 21 is protective in experimental diabetes-associated atherosclerosis
}

\author{
Bryna S. M. Chow ${ }^{1} \cdot$ Christine Koulis $^{1} \cdot$ Pooja Krishnaswamy $^{1} \cdot$ Ulrike M. Steckelings $^{2}$ • \\ Thomas Unger $^{3} \cdot$ Mark E. Cooper $^{1} \cdot$ Karin A. Jandeleit-Dahm $^{1} \cdot$ Terri J. Allen ${ }^{1}$
}

Received: 20 January 2016 / Accepted: 20 April 2016 / Published online: 11 May 2016

(C) Springer-Verlag Berlin Heidelberg 2016

\begin{abstract}
Aims/hypothesis Angiotensin II is well-recognised to be a key mediator in driving the pathological events of diabetesassociated atherosclerosis via signalling through its angiotensin II type 1 receptor $\left(\mathrm{AT}_{1} \mathrm{R}\right)$ subtype. However, its actions via the angiotensin II type 2 receptor $\left(\mathrm{AT}_{2} \mathrm{R}\right)$ subtype are still poorly understood. This study is the first to investigate the role of the novel selective $\mathrm{AT}_{2} \mathrm{R}$ agonist, Compound 21 (C21) in an experimental model of diabetes-associated atherosclerosis (DAA). Methods Streptozotocin-induced diabetic Apoe-knockout mice were treated with vehicle $(0.1 \mathrm{~mol} / \mathrm{l}$ citrate buffer $), \mathrm{C} 21$ ( $1 \mathrm{mg} / \mathrm{kg}$ per day), candesartan cilexetil ( $4 \mathrm{mg} / \mathrm{kg}$ per day) or $\mathrm{C} 21+$ candesartan cilexetil over a 20 week period. In vitro models of DAA using human aortic endothelial cells and monocyte cultures treated with $\mathrm{C} 21$ were also performed. At the end of the experiments, assessment of plaque content and markers of oxidative stress, inflammation and fibrosis were conducted.
\end{abstract}

Bryna S. M. Chow and Christine Koulis contributed equally to the manuscript.

Electronic supplementary material The online version of this article (doi:10.1007/s00125-016-3977-5) contains peer-reviewed but unedited supplementary material, which is available to authorised users.

Terri J. Allen

terri.allen@bakeridi.edu.au

1 JDRF Danielle Alberti Memorial Centre for Diabetic Complications, Diabetic Complications Division, Baker IDI Heart and Diabetes

Research Institute, 75 Commercial Road, P. O. Box 6492, Melbourne, VIC 3004, Australia

2 IMM-Department of Cardiovascular and Renal Research, University of Southern Denmark, Odense, Denmark

3 School for Cardiovascular Diseases, Maastricht University, Maastricht, the Netherlands
Results $\mathrm{C} 21$ treatment significantly attenuated aortic plaque deposition in a mouse model of DAA in vivo, in association with a decreased infiltration of macrophages and mediators of inflammation, oxidative stress and fibrosis. On the other hand, combination therapy with $\mathrm{C} 21$ and candesartan $\left(\mathrm{AT}_{1} \mathrm{R}\right.$ antagonist) appeared to have a limited additive effect in attenuating the pathology of DAA when compared with either treatment alone. Similarly, C21 was found to confer profound antiatherosclerotic actions at the in vitro level, particularly in the setting of hyperglycaemia. Strikingly, these atheroprotective actions of $\mathrm{C} 21$ were completely blocked by the $\mathrm{AT}_{2} \mathrm{R}$ antagonist PD123319.

Conclusions/interpretation Taken together, these findings provide novel mechanistic and potential therapeutic insights into $\mathrm{C} 21$ as a monotherapy agent against DAA.

Keywords Angiotensin II $\cdot \mathrm{AT}_{2}$ receptor $\cdot$ Atherosclerosis · Compound $21 \cdot$ Diabetes

$\begin{array}{ll}\text { Abbreviations } \\ \text { Ang II } & \text { Angiotensin II } \\ \mathrm{ARB} & \text { Angiotensin receptor blocker } \\ \mathrm{AT}_{1} \mathrm{R} & \text { Angiotensin II type 1 receptor } \\ \mathrm{AT}_{2} \mathrm{R} & \text { Angiotensin II type } 2 \text { receptor } \\ \mathrm{C} 21 & \text { Compound } 21 \\ \mathrm{DAA} & \text { Diabetes-associated atherosclerosis } \\ \mathrm{HAEC} & \text { Human aortic endothelial cells } \\ \mathrm{MCP} & \text { Monocyte-chemoattractant protein } \\ \mathrm{NOX} & \text { NADPH oxidase } \\ \mathrm{RAS} & \text { Renin-angiotensin system } \\ \mathrm{STZ} & \text { Streptozotocin } \\ \text { TxR } & \text { Thromboxane receptor } \\ \text { VCAM-1 } & \text { Vascular cell adhesion molecule-1 }\end{array}$




\section{Introduction}

Overactivation of the renin-angiotensin system (RAS) is wellrecognised to be a major underlying pathological mechanism that drives the development of diabetic vascular disease, with its effector peptide, angiotensin II (Ang II), being the main mediator [1]. Pharmacological inhibition of the RAS by targeting either Ang II production with an angiotensinconverting enzyme inhibitor or the activity of Ang II with an angiotensin receptor blocker (ARB) remains first-line treatment for patients with diabetes and vascular disease [2]. However, it has been proposed that the beneficial effects of these treatments are out of proportion with the magnitude of blood pressure reduction, suggesting more direct effects on end organs, including the macrovasculature.

Although Ang II binds with similar affinity to both the $\mathrm{AT}_{1}$ and $\mathrm{AT}_{2}$ receptor subtypes [3], the relative importance of these receptors in modulating vascular injury remains poorly understood. Angiotensin II type 1 receptors $\left(\mathrm{AT}_{1} \mathrm{Rs}\right)$ are primarily involved in mediating the pathophysiological actions of Ang II, including its ability to regulate blood pressure, vasoconstriction and cellular differentiation and promote hypertrophy [4]. Strikingly, Ang II negatively regulates its classical actions through the angiotensin II type 2 receptors $\left(\mathrm{AT}_{2} \mathrm{Rs}\right)$ [5], with this receptor subtype being markedly upregulated in numerous diseased states, including atherosclerosis [6, 7], possibly to counterbalance the adverse effects mediated by the $\mathrm{AT}_{1} \mathrm{R}$. Taken together, these actions highlight the potential of the $\mathrm{AT}_{2} \mathrm{R}$ as a key therapeutic target. With numerous studies focusing on the role of the $\mathrm{AT}_{2} \mathrm{R}$ in the non-diabetes setting [8-10], the vascular actions of this receptor in the context of diabetes still remains unclear. Given our previous findings that selective activation of the $\mathrm{AT}_{2} \mathrm{R}$ by a novel non-peptide agonist, Compound 21 (C21), significantly ameliorated the progression of nephropathy in an insulin-deficient model [11], we aimed to further investigate the protective role of $\mathrm{C} 21$ on macrovascular disease in this diabetes model. $\mathrm{C} 21$ is a highly specific $\mathrm{AT}_{2} \mathrm{R}$ agonist, with a $\mathrm{K}_{\mathrm{i}}$ value of $0.4 \mathrm{nmol} / \mathrm{l}$ and $>1000 \mathrm{nmol} / 1$ for the $\mathrm{AT}_{2} \mathrm{R}$ and $\mathrm{AT}_{1} \mathrm{R}$, respectively [12]. This study is the first to delineate the vasoprotective role of C21 in an experimental model of streptozotocin (STZ)-induced insulin-deficient diabetes in vivo, followed by extension of the findings to explore potential underlying mechanisms in vitro.

\section{Methods}

Animals Male apolipoprotein E-knockout $\left(\mathrm{Apoe}^{-/-}\right)$mice on a C57BL6/J background (Jackson Laboratory, Sacramento, CA, USA) were used throughout the study based on previous findings that the mice in this model develop accelerated DAA upon the induction of diabetes and so constitute an appropriate model of DAA [13]. Mice were housed and maintained on a $12 \mathrm{~h}$ light-dark cycle in a pathogen-free environment and had free access to water and rodent lab chow (Specialty Feeds, Glen Forrest, WA, Australia). Experiments were conducted in accordance with the Australian code of practice for the care and use of laboratory animals for scientific purposes.

In vivo experimental procedure Seven-week-old $A p o e^{-/-}$ mice were rendered diabetic via a daily intraperitoneal injection of STZ (Sigma-Aldrich, St Louis, MO, USA) at a dose of $55 \mathrm{mg} / \mathrm{kg}$ per day over a period of 5 days. Animals with blood glucose and $\mathrm{HbA}_{1 \mathrm{c}}$ levels greater than $15 \mathrm{mmol} / \mathrm{l}$ and $10 \%$ $(85.8 \mathrm{mmol} / \mathrm{mol})$, respectively, after 10 days post-STZ-administration, were included in the study as diabetic. Diabetic mice were randomised and treated with vehicle $(0.1 \mathrm{~mol} / \mathrm{l}$ citrate buffer), C21 (1 mg/kg per day; Vicore Pharma, Göteborg, Sweden), the $\mathrm{AT}_{1} \mathrm{R}$ antagonist candesartan cilexetil (4 mg/kg per day; AstraZeneca Södertälje, Sweden) or C21 + candesartan treatment, via daily gavaging, over a 20 week period. These concentrations of $\mathrm{C} 21$ and candesartan had previously been shown to successfully ameliorate diabetic nephropathy $[11,14]$. Non-diabetic mice treated in the absence or presence of C21 were also studied. At the end of the study, mice were killed and aortic tissues were excised for analysis. For assessment of body weight, metabolic variables and blood pressure, mice were placed in individual metabolic cages (Iffa Credo, L'Arbresele, France) for a period of $24 \mathrm{~h}$ and performed as described [11].

Cell culture The atherosclerotic properties of the $\mathrm{AT}_{2} \mathrm{R}$ were further investigated in human aortic endothelial cells (HAEC) and monocyte cultures (THP-1) (obtained from ATCC, Manassas, VA, USA). Experiments were performed three or four separate times in duplicate. Cells were regularly tested for mycoplasma contamination by the media services (Baker IDI Heart and Diabetes Institute, Australia).

HAECs were cultured in endothelial growth media supplemented with EGM-2 Bulletkit (Lonza, Allendale, NJ, USA). In all experiments, EGM-2 media containing $5.6 \mathrm{mmol} / \mathrm{l}$ glucose was used as the normal-glucose condition, while EGM-2 media containing $25 \mathrm{mmol} / \mathrm{l}$ glucose (Sigma-Aldrich) was used as high-glucose condition.

THP-1 cells were maintained in RPMI supplemented with $10 \%$ fetal calf serum, penicillin $(50 \mathrm{U} / \mathrm{ml})$ and streptomycin $(50 \mu \mathrm{g} / \mathrm{ml})$. To induce monocyte-macrophage differentiation, cells were treated with phorbol-12-myristate-13-acetate ( $1 \mu \mathrm{mol} / \mathrm{l}$; Sigma-Aldrich) 3 days before subjecting the cells to the various treatments.

In vitro experimental procedure To determine the optimal dose of C21, HAEC and THP-1 cultures (tested negative for mycoplasma contamination) were seeded into 12 -well plates at equal density $\left(1 \times 10^{5}\right.$ to $1.5 \times 10^{5}$ cells/well $)$ and treated with 
C21 $(0.1-1.0 \mu \mathrm{mol} / \mathrm{l})$ in both normal- $(5 \mathrm{mmol} / \mathrm{l})$ and highglucose $(25 \mathrm{mmol} / \mathrm{l})$ conditions for $72 \mathrm{~h}$. Additional studies were also conducted to determine the following: (1) whether the optimal dose at which C21 inhibited high-glucosestimulated inflammatory and fibrotic markers was able to inhibit Ang II-mediated activity; (2) whether the ability of C21 to mediate this activity occurred specifically through the $\mathrm{AT}_{2} \mathrm{R}$, by ascertaining whether $\mathrm{C} 21$-induced effects in these cells were blocked by the $\mathrm{AT}_{2} \mathrm{R}$ antagonist PD123319 ( 5 umol/1; Cayman Chemical, Ann Arbour, MI, USA), (3) whether $\mathrm{C} 21$ as a combination therapy with an $\mathrm{AT}_{1} \mathrm{R}$ blocker, candesartan cilexetil $(10 \mu \mathrm{mol} / \mathrm{l})$ had any additive effect in attenuating DAA and (4) whether the candesartan cilexetilmediated effects were altered by PD123319. At the end of each experiment, RNA and protein were extracted from the cell layer with Trizol reagent (Life Technologies, Rockville, $\mathrm{MD}$, USA) for subsequent analysis.

\section{Evaluation of atherosclerotic plaque size and content} Plaque area was quantified in an en face manner, as described previously [15]. Total and segmental plaque areas were quantified as a percentage area of aorta stained (Adobe Photoshop, version 7.0; Adobe Systems, Chatswood, NSW, Australia).

Frozen sections of aortic sinus were stained with Oil Red O solution (Sigma-Aldrich) for $1 \mathrm{~h}$ followed by counterstaining with haematoxylin. Measurement of necrotic cores was subsequently quantified as described previously [16]. Results were expressed as area of necrotic core per lesion.

Immunohistochemistry Paraffin sections of aorta were stained for vascular cell adhesion molecule-1 (VCAM-1; 1:250 dilution; BD Pharmingen, San Diego, CA, USA), as described previously [17]. Positive-stained sections were quantified using Image-Pro Analyser 7.0 (Media Cybernetics, Bethesda, MD, USA) and stained areas were expressed as either stained area $\left(\mu \mathrm{m}^{2}\right)$ or percentage of the total plaque area.

Quantitative real-time PCR analysis Expression of genes encoding several markers of DAA were analysed by quantitative real-time PCR (qPCR) using the Taqman System on an ABI Prism 7500 Sequence Detector (Applied Biosystems, Foster City, CA, USA) as described previously [11]. Gene expression was normalised to $18 \mathrm{~S}$ mRNA and reported as relative ratio to the control group (either the non-diabetic mice or normal-glucose-treated cells), which was assigned an arbitrary value of 1 .

Western blotting Proteins $(10 \mu \mathrm{g})$ were electrophoresed on $10.5 \%$ acrylamide gels under reducing conditions. Western blot analyses were performed with primary antibodies to either $\mathrm{AT}_{2} \mathrm{R}$ (H-143, 1:1,000 dilution; Santa Cruz Biotechnology, Santa Cruz, CA, USA) or $\mathrm{AT}_{1} \mathrm{R}(\mathrm{N}-10,1: 1,000$ dilution;
Santa Cruz) and assessed with appropriate secondary antibodies. The housekeeping protein, $\alpha$-tubulin (Sigma-Aldrich) was included to demonstrate equal loading of protein samples. Blots were detected using an enhanced chemiluminescent detection kit (Sigma-Aldrich) followed by quantification by densitometry using Quantity-One 4.5.2 software (Bio-Rad Laboratories, Richmond, CA, USA).

Statistical analysis Data were analysed by one-way ANOVA using SPSS 20.0 software (IBM, St Leonards, NSW, Australia). Post hoc comparisons were performed among the various groups using Fisher's least significant difference method. Data are expressed as mean \pm SEM, with $p<0.05$ considered as statistically significant.

\section{Results}

Metabolic variables STZ-treated Apoe $e^{-/-}$mice developed sustained hyperglycaemia over the 20 week experimental period with elevated blood glucose and $\mathrm{HbA}_{1 \mathrm{c}}$ levels $(p<0.01$ vs non-diabetic mice). Diabetic mice showed reduced body weight and elevated levels of total plasma cholesterol and triacylglycerol (Table 1). Neither treatment with C21 alone nor candesartan alone affected any of these variables in either non-diabetic (control) or diabetic mice. While C21 did not have any systemic haemodynamic effect in either normoglycaemic or hyperglycaemic groups, administration of candesartan alone and in combination with $\mathrm{C} 21$ significantly reduced blood pressure in diabetic mice.

Atherosclerotic plaque area En face analysis of the whole aorta revealed a twofold increase in plaque area in diabetic mice compared with their non-diabetic counterparts $(p<0.05)$ (Fig. 1). Similar findings were also observed in the aortic arch and thoracic and abdominal segments. C21-treatment significantly reduced atherosclerotic lesion area in diabetic mice ( $p<0.05$ vs diabetic mice). While a similar reduction was seen with candesartan treatment alone, there was no further decrease seen in diabetic mice co-treated with $\mathrm{C} 21$ and candesartan. Importantly, C21 had no effect in modulating plaque lesion in non-diabetic mice.

Sinus plaque content Diabetic mice demonstrated a twofold increase in lipid deposition compared with their non-diabetic counterparts (Fig. 2a; $p<0.01$ ). This accumulation of lipid within the atherosclerotic plaque was ameliorated by treatment with either $\mathrm{C} 21$ or candesartan alone (both $p<0.05$ vs diabetic mice) and by co-treatment with $\mathrm{C} 21$ and candesartan when compared with diabetic mice ( $p<0.01$ vs diabetic mice). The combination treatment showed a trend towards a further modest reduction in plaque content when compared with either treatment alone ( $p=0.39$ vs diabetic mice treated with 
Table 1 Metabolic variables of non-diabetic and diabetic $A p o e^{-/-}$mice treated in the absence or presence of $\mathrm{AT}_{2} \mathrm{R}$ agonist $\mathrm{C} 21$ and/or $\mathrm{AT}_{1} \mathrm{R}$ antagonist candesartan

\begin{tabular}{|c|c|c|c|c|c|c|}
\hline \multirow[t]{2}{*}{ Variables } & \multicolumn{2}{|c|}{ Control mice } & \multicolumn{4}{|c|}{ Diabetic mice } \\
\hline & Vehicle & $\mathrm{C} 21$ & Vehicle & $\mathrm{C} 21$ & Candesartan & Candesartan $+\mathrm{C} 21$ \\
\hline Body weight (g) & $30.5 \pm 0.5$ & $30.5 \pm 0.3$ & $26.9 \pm 0.8^{* *}$ & $22.8 \pm 0.8^{* *}$ & $25.7 \pm 0.8^{* *}$ & $27.8 \pm 1.3 *$ \\
\hline Plasma glucose $(\mathrm{mmol} / \mathrm{l})$ & $10.0 \pm 0.4$ & $13.4 \pm 0.9$ & $23.5 \pm 2.1 * *$ & $20.3 \pm 2.0 * *$ & $20.9 \pm 2.0^{* *}$ & $19.1 \pm 2.2 * *$ \\
\hline $\mathrm{HbA}_{1 \mathrm{c}}(\%)$ & $3.9 \pm 0.1$ & $4.2 \pm 0.1$ & $12.4 \pm 0.7 * *$ & $12.7 \pm 0.6^{* *}$ & $15.2 \pm 2.2 * *$ & $15.2 \pm 1.8^{* *}$ \\
\hline $\mathrm{HbA}_{1 \mathrm{c}}(\mathrm{mmol} / \mathrm{mol})$ & $19 \pm 1$ & $22 \pm 1$ & $112 \pm 8^{* *}$ & $115 \pm 7 * *$ & $143 \pm 24 * *$ & $143 \pm 19^{* *}$ \\
\hline Total cholesterol $(\mathrm{mmol} / \mathrm{l})$ & $9.0 \pm 0.7$ & $10.0 \pm 0.6$ & $14.1 \pm 1.0^{* *}$ & $15.3 \pm 1.7 * *$ & $14.5 \pm 0.7 * *$ & $14.1 \pm 1.1 * *$ \\
\hline Triacylglycerol (mmol/l) & $1.5 \pm 0.2$ & $1.2 \pm 0.2$ & $2.7 \pm 0.4 * *$ & $3.6 \pm 0.2 * *$ & $1.9 \pm 0.4^{* *}$ & $1.1 \pm 0.3^{* * \dagger}$ \\
\hline Systolic BP (mmHg) & $95 \pm 1$ & $94 \pm 2$ & $96 \pm 1$ & $95 \pm 2$ & $87 \pm 2 * * \dagger \dagger$ & $87 \pm 2 * * \dagger \dagger$ \\
\hline
\end{tabular}

Data are shown as mean \pm SEM, $n=14-21$ mice per group

${ }^{*} p<0.05$ and ${ }^{* *} p<0.01$ vs vehicle-treated control (non-diabetic) group; ${ }^{\dagger} p<0.05$ and ${ }^{\dagger \dagger} p<0.01$ vs vehicle-treated diabetic mice

Fig. 1 Atherosclerotic lesions in mouse aorta stained with Oil Red $\mathrm{O}$ and counterstained with haematoxylin (a) and total atherosclerotic plaque area (as percentage area of aorta stained) in the whole aorta (b) and within the $\operatorname{arch}(\mathbf{c})$ and thoracic (d) and abdominal (e) aortic segments. Magnification $\times 4.2$. Data are expressed as the mean \pm SEM of $n=6-13$ mice per group.

$* * p<0.01$ vs vehicle-treated control (non-diabetic) group; ${ }^{\dagger} p<0.05$ and ${ }^{\dagger \dagger} p<0.01$ vs diabetic group. Cand,

candesartan; CTL, control; Diab, diabetic a
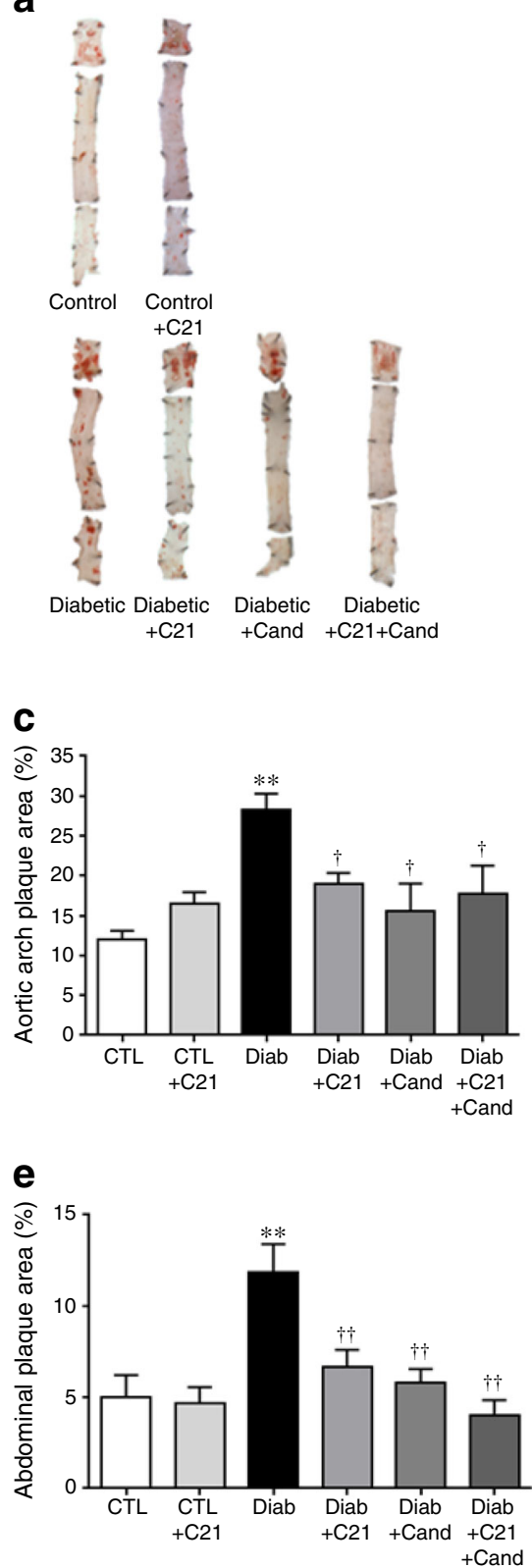

b
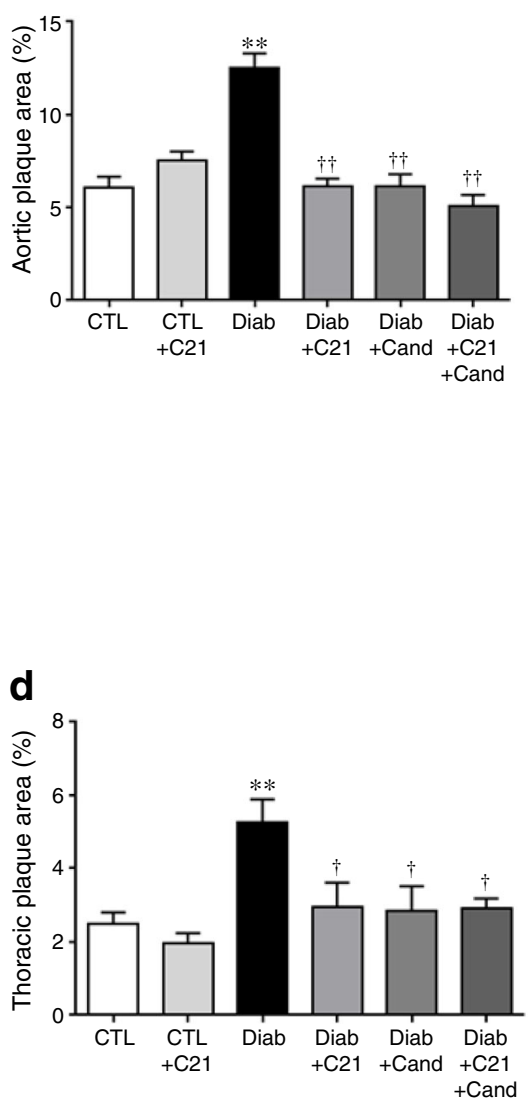
a
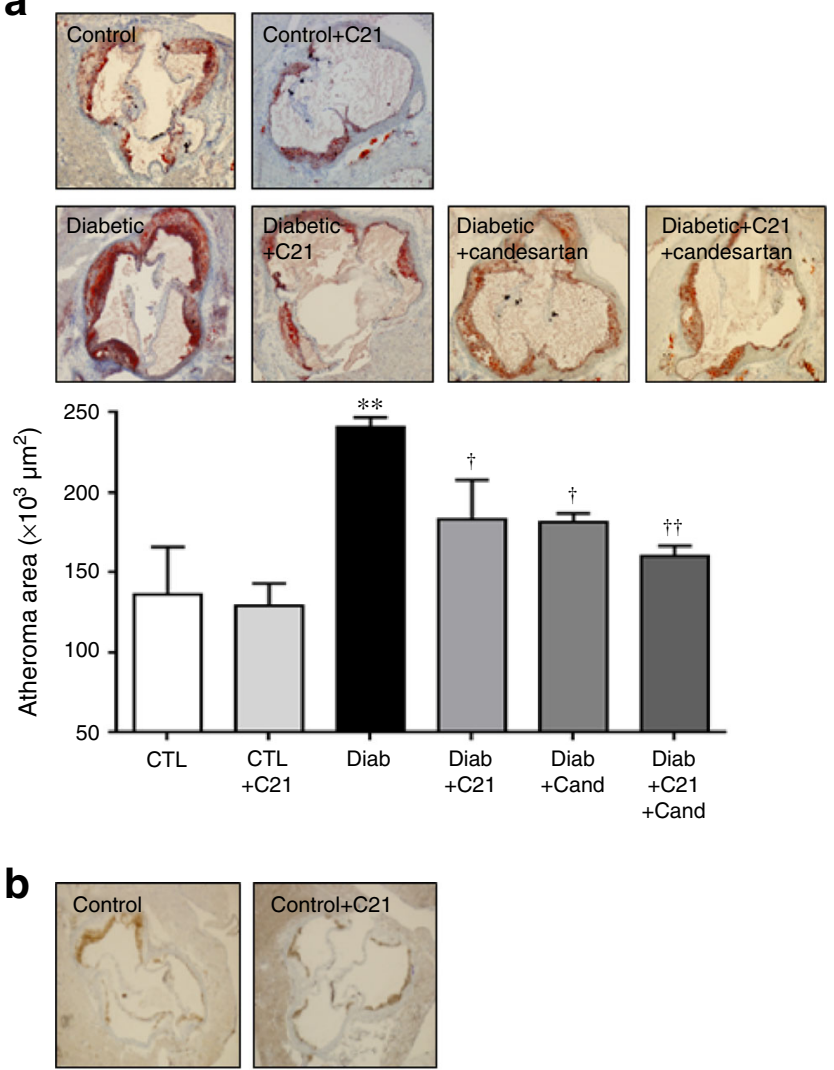

b
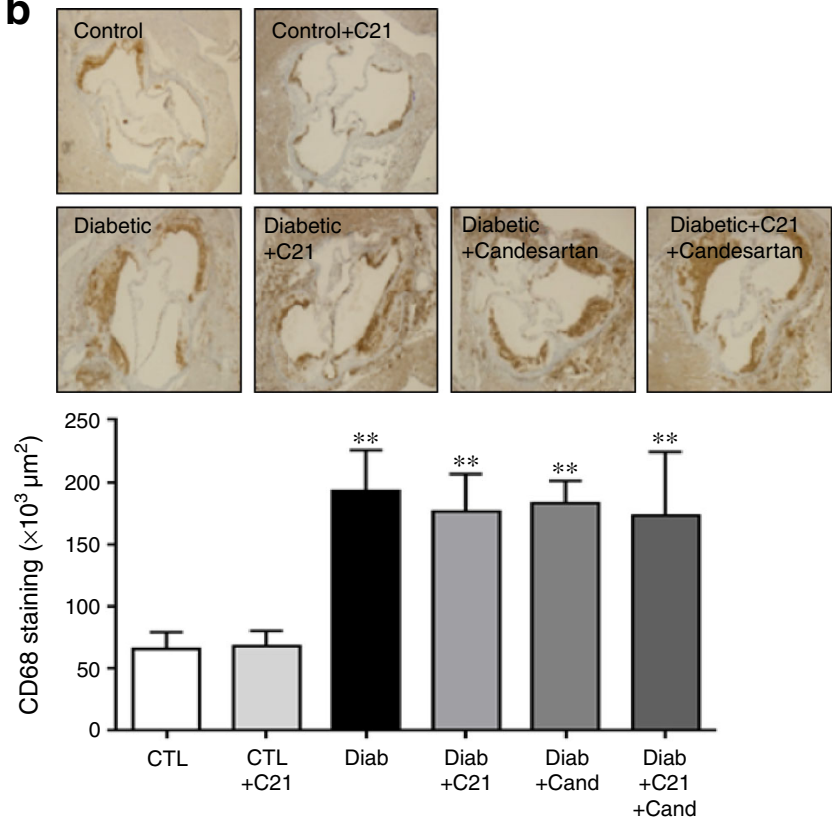

Fig. 2 (a) Lipid content within the atherosclerotic plaque in mouse aorta. (b) CD68 staining. Magnification $\times 4.2$. Data are expressed as the mean \pm SEM of 5-11 mice per group. ${ }^{* *} p<0.01$ vs vehicle-treated control (nondiabetic) group; ${ }^{\dagger} p<0.05$ and ${ }^{\dagger \dagger} p<0.01$ vs diabetic group. Cand, candesartan; CTL, control; Diab, diabetic

$\mathrm{C} 21 ; p=0.05$ vs diabetic mice treated with candesartan alone). However, C21 had no effect in modulating lipid content within the intimal layer of the aortic sinus in non-diabetic mice.

Macrophage infiltration Immunohistochemically stained aortic sections from diabetic mice demonstrated a significant increase in CD68 protein expression (Fig. $2 \mathrm{~b} ; p<0.01$ vs non- diabetic mice). Neither C21 nor candesartan treatment inhibited diabetes-induced macrophage infiltration.

Aortic expression of $\mathrm{AT}_{\mathbf{2}} \mathrm{R}$ and $\mathrm{AT}_{\mathbf{1}} \mathbf{R}$ qPCR analysis performed on mouse aorta confirmed the expression of both $\mathrm{AT}_{2} \mathrm{Rs}$ and $\mathrm{AT}_{1}$ Rs. mRNA levels of $A t_{2} r$ (also known as Agtr2) were significantly upregulated in diabetic mice $(p<0.05$ vs non-diabetic mice; Fig. 3a) but were not modulated by $\mathrm{C} 21$, candesartan or $\mathrm{C} 21$ + candesartan treatment. In contrast, no significant difference in $A t_{1} r$ (also known as Agtrl) gene expression was observed when comparing the non-diabetic and diabetic mouse groups (Fig. 3b). Moreover, $A t_{1} r$ expression remained unchanged in all treatment groups.

Aortic expression of the adhesion marker VCAM-1 With the adhesion of monocytes to endothelial cells considered a critical step in the initiation and development of DAA, VCAM1 expression was examined at both the gene and protein level. qPCR analysis revealed a significant upregulation in Vcam-1 (also known as Vcam 1) gene expression in diabetic mice $(p<0.01$ vs non-diabetic mice, Fig. 3c). While C21 treatment appeared to induce a trend towards a reduction in $V c a m-1$ gene expression in diabetic mice, this $\mathrm{AT}_{2} \mathrm{R}$ agonist significantly inhibited diabetes-induced VCAM-1 expression at the protein level ( $p<0.05$ vs diabetic mice; Fig. 3d). Conversely, a significant reduction in Vcam-1 mRNA and VCAM-1 protein expression was observed in diabetic mice treated with candesartan alone and in combination with $\mathrm{C} 21$. Nonetheless, both qPCR and immunohistochemical analyses demonstrated that combination therapy with $\mathrm{C} 21$ and candesartan produced no additive effect in further reducing diabetes-induced VCAM-1 expression, when compared with either treatment alone. Importantly, C21 had no effect in modulating VCAM-1 expression at the gene or protein level in nondiabetic mice.

Aortic expression of markers of oxidative stress, inflammation and fibrosis Expression of p47phox, NADPH oxidase (NOX)-1 and NOX-4 was determined as part of the assessment of oxidative stress, while that of monocytechemoattractant protein-1 (MCP-1) and TGF- $\beta 1$ was examined to assess inflammatory and fibrotic pathways. Treatment with either $\mathrm{C} 21$ or candesartan significantly ameliorated diabetes-induced p47phox (also known as Ncf1), Noxl, Mcp-1 (Ccl2) and Tgf- $\beta 1$ (Tgfbl) mRNA levels $(p<0.05$ vs diabetic mice; Fig. 3e, f, h, i); with Nox4 expression this amelioration was produced by only $\mathrm{C} 21$ and not candesartan (Fig. 3g). Co-administration of C21 and candesartan markedly inhibited the expression of all the analysed markers in diabetic mice ( $p<0.05$ vs diabetic mice) while again no synergistic effect was seen when compared with either therapy alone. Importantly, C21 did not influence any of the analysed markers in non-diabetic mice. 
Fig. 3 (a-e) $A t_{2} r(\mathbf{a}), A t_{1} r$ (b) and Vcam-1 (c) mRNA levels in mouse aorta; also shown are the representative photomicrographs (magnification $\times 45$ ) of VCAM-1stained aortic sinus (d). (e-i) Aortic mRNA levels of $p 47$ phox (e), Noxl (f), Nox4 (g), Mcp-1 (h) and $T g f-\beta$ (i). Data are shown as the mean \pm SEM of 5-12 mice per group. mRNA levels were normalised to $18 \mathrm{~S}$ mRNA and reported as relative ratio to the control group. ${ }^{*} p<0.05$ and ${ }^{* *} p<0.01$ vs vehicle-treated control (non-diabetic); ${ }^{\dagger} p<0.05$ and ${ }^{\dagger \dagger} p<0.01$ vs diabetic group. Cand, candesartan; CTL, control; Diab, diabetic a

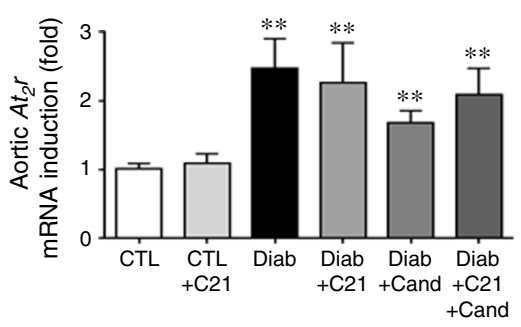

C

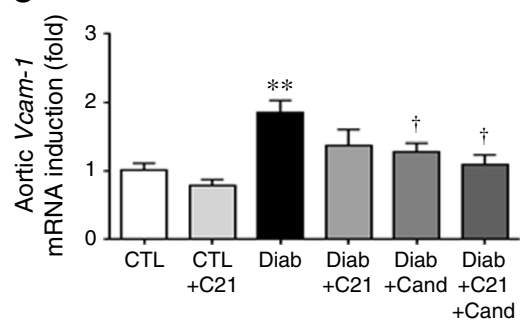

e

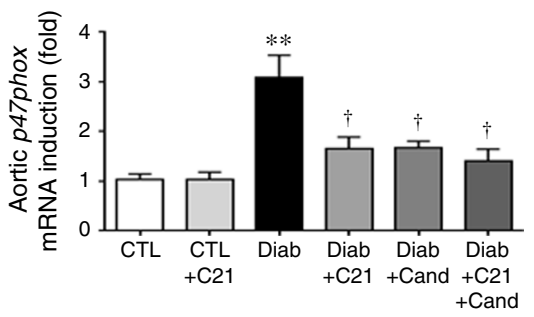

f

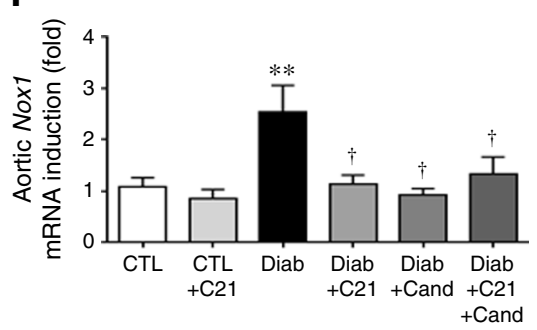

h

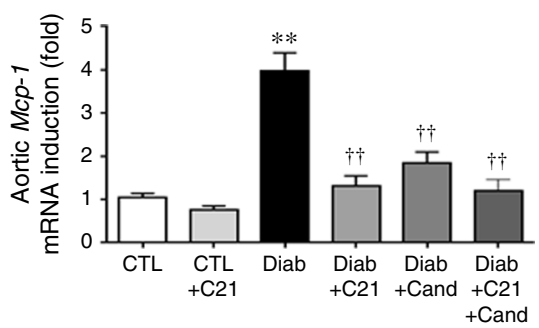

b

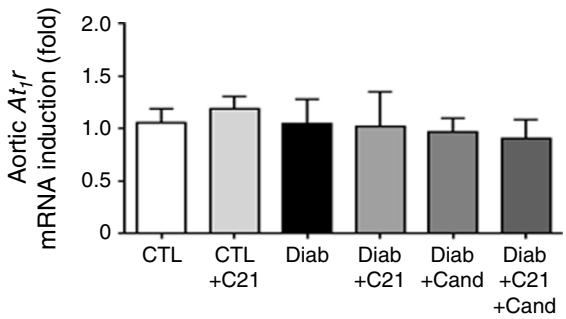

d
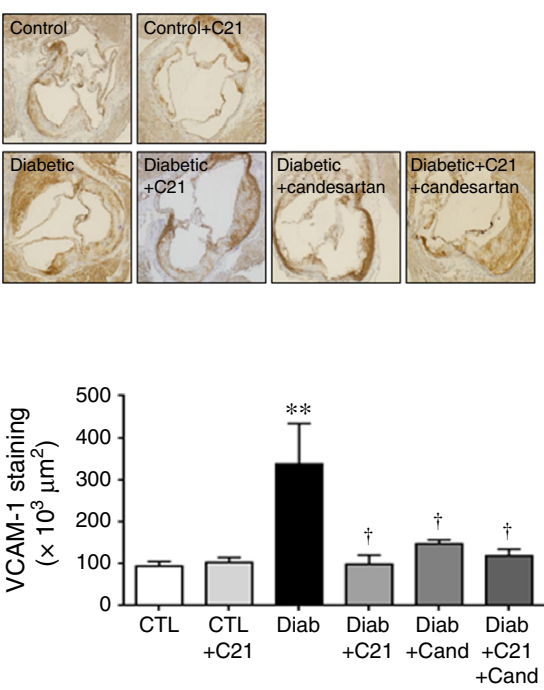

g

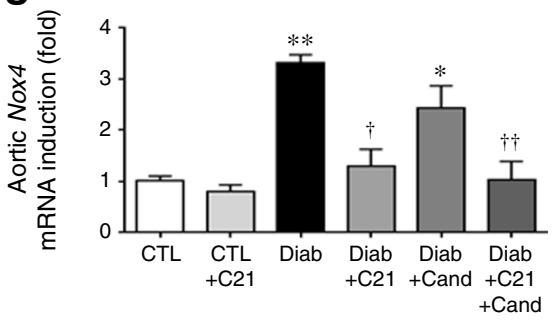

i

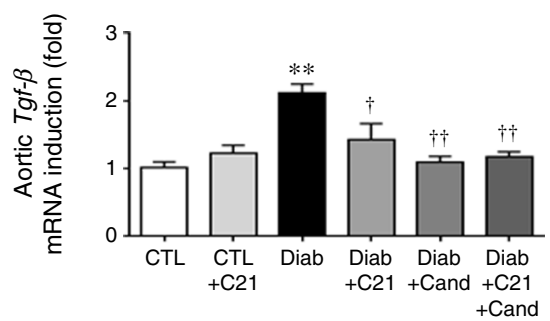

In vitro effect of C21 on high-glucose- and Ang IIstimulated cells Consistent with our in vivo data, qPCR analysis of mRNA showed that markers of inflammation (ICAM-1 [ICAMI]), oxidative stress (NOX-4) and fibrosis $(T G F-\beta, C T G F)$ were upregulated in hyperglycaemic conditions in both HAEC and THP-1 cells $(p<0.05$ vs normal-glucose-treated cells) (Fig. 4). Administration of C21 significantly inhibited the upregulation of these high-glucose-induced markers dose dependently, being most effective at a concentration of $1 \mu \mathrm{mol} / 1$ in both cell populations. Moreover, $\mathrm{C} 21$ at this dose significantly inhibited Ang II-induced effects (Figs 5, 6). Strikingly, 
Fig. 4 ICAM-1, NOX4, TGF- $\beta$ and $C T G F$ mRNA levels from HAEC (a) and THP-1 cells (b) cultured in either normal $(5 \mathrm{mmol} / \mathrm{l})$ or high $(25 \mathrm{mmol} / \mathrm{l})$ glucose conditions. Cells were treated with $\mathrm{C} 21(0.1-1.0 \mu \mathrm{mol} / \mathrm{l})$; mannitol ( $25 \mathrm{mmol} / \mathrm{l})$-treated cells served as osmotic control. Data are shown as the mean \pm SEM; $n=3$ or 4 . mRNA levels were normalised to $18 \mathrm{~S}$ mRNA and reported as relative ratio to the normal glucose group. $* p<0.05$ and $* * p<0.01$ vs normal-glucose-treated cells; ${ }^{\dagger} p<0.05$ and ${ }^{\dagger \dagger} p<0.01$ vs highglucose-treated cells a
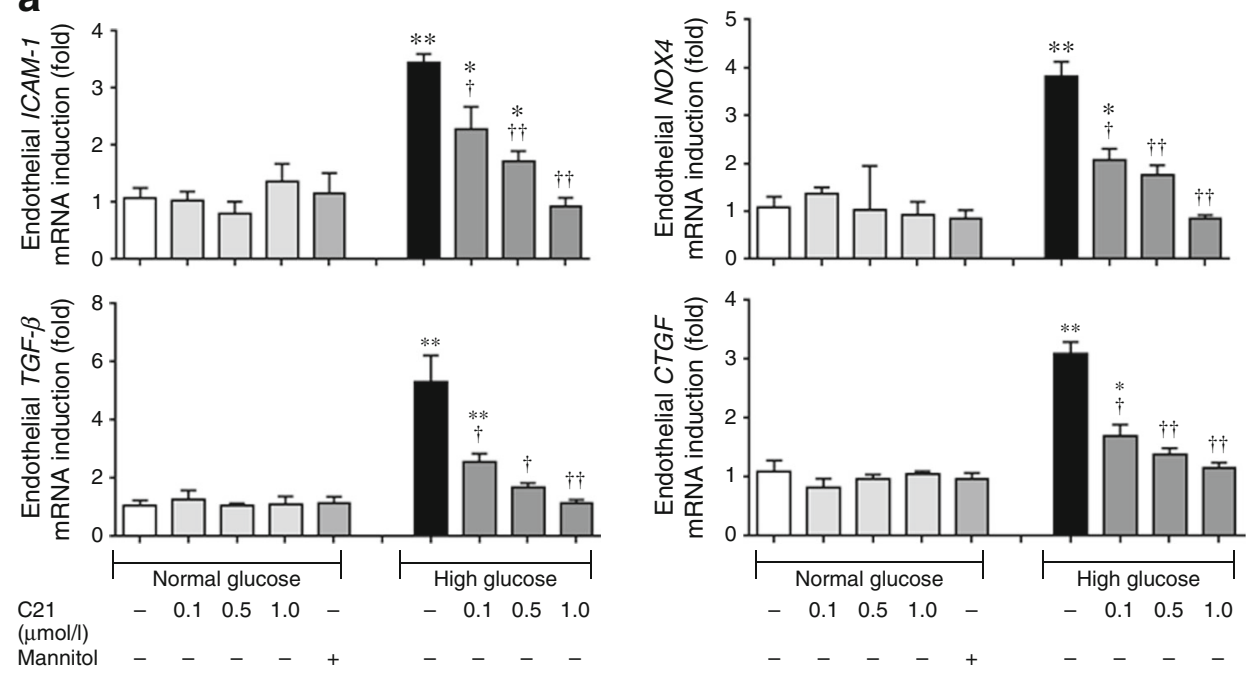

b
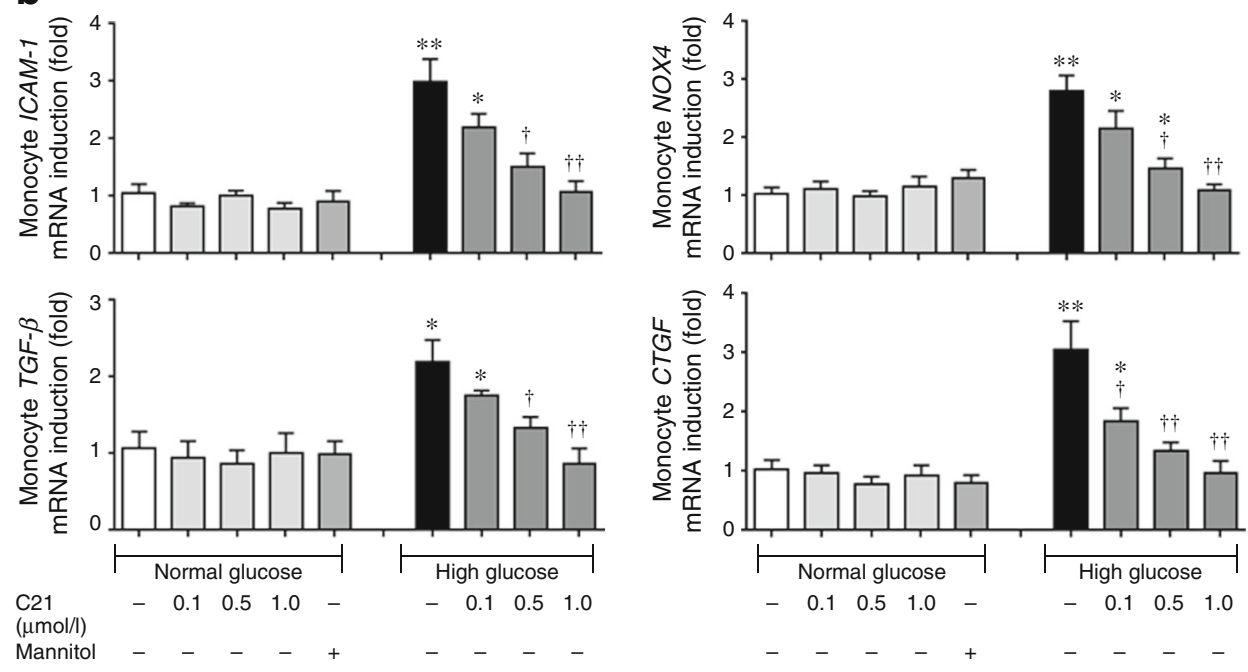

these protective effects of $\mathrm{C} 21$ were completely abolished by the $\mathrm{AT}_{2} \mathrm{R}$ antagonist, PD123319 in both cell types (Figs 5, 6). While C21 $(1 \mu \mathrm{mol} / \mathrm{l})$ had similar efficacy to that of candesartan $(10 \mu \mathrm{mol} / \mathrm{l})$, co-administration of $\mathrm{C} 21$ and candesartan produced no additive effect in inhibiting high-glucose- and Ang-II-induced ICAM-1, NOX-4, $T G F-\beta$ and Ctgf expression (Figs 5, 6). Based on the similar efficacy of candesartan and $\mathrm{C} 21$ in attenuating the pathology of DAA, further delineation of the involvement of the $\mathrm{AT}_{2} \mathrm{R}$ with respect to the effects of the ARB were further studied in HAEC. Interestingly, candesartanmediated protective effects were blocked by the $\mathrm{AT}_{2} \mathrm{R}$ antagonist, PD123319 (Fig. 5).

In vitro expression of $A T_{2} R$ and $A T_{1} R$ Western blot analysis confirmed the expression of both $\mathrm{AT}_{2} \mathrm{R}$ and $\mathrm{AT}_{1} \mathrm{R}$ in HAEC and THP-1 cells (Fig. 7). Although $\mathrm{AT}_{2} \mathrm{R}$ protein expression was significantly elevated in cells cultured in the high-glucose condition, neither $\mathrm{C} 21$ nor the $\mathrm{AT}_{2} \mathrm{R}$ and $\mathrm{AT}_{1} \mathrm{R}$ inhibitors (PD123319 and candesartan, respectively) had any effect in modulating $\mathrm{AT}_{2} \mathrm{R}$ expression. In contrast, $\mathrm{AT}_{1} \mathrm{R}$ expression remained unchanged in all conditions (Fig. 7). Importantly, both $\mathrm{AT}_{2} \mathrm{R}$ and $\mathrm{AT}_{1} \mathrm{R}$ protein expression remained unchanged in normal-glucose conditions (data not shown). Similar results were also observed at the gene level (electronic supplementary material [ESM] Fig. 1).

\section{Discussion}

$\mathrm{AT}_{2} \mathrm{R}$ activation is increasingly recognised to confer protective effects in numerous disease states including atherosclerosis $[18,19]$, which is considered to be the major contributor to premature mortality and morbidity. However, the biological effects mediated by the $\mathrm{AT}_{2} \mathrm{R}$ with respect to DAA have not 
Fig. 5 ICAM- $1, N O X 4, T G F-\beta$ and $C T G F$ mRNA levels from HAEC cells cultured in either normal $(5 \mathrm{mmol} / \mathrm{l})$ or high ( $25 \mathrm{mmol} / \mathrm{l}$ ) glucose conditions stimulated in the absence (a) or presence $(\mathbf{b})$ of AngII $(3 \mu \mathrm{mol} / \mathrm{l})$ and treated with either $\mathrm{C} 21$ ( $1 \mu \mathrm{mol} / \mathrm{l})$, PD123319 (5 $\mu \mathrm{mol} / \mathrm{l})$, candesartan $(10 \mu \mathrm{mol} / \mathrm{l})$, candesartan+PD123319, C21+ PD123319 or C21+candesartan. Cells treated with mannitol ( $25 \mathrm{mmol} / \mathrm{l}$ ) served as osmotic control. Data are shown as the mean $\pm \mathrm{SEM} ; n=3-10$. mRNA levels were normalised to $18 \mathrm{~S}$ mRNA and reported as relative ratio to the normal glucose group. ${ }^{*} p<0.05$ and $* * p<0.01$ vs normal glucose (NG); ${ }^{\dagger} p<0.05$ and ${ }^{\dagger p} p<0.01$ vs high glucose (HG); ${ }^{\sharp} p<0.01$ vs HG $+\mathrm{C} 21$; ${ }^{\S} p<0.05$ and ${ }^{\S \S} p<0.01$ vs $\mathrm{HG}^{+}$ candesartan; ${ }^{\top \pi} p<0.01 \mathrm{vs} \mathrm{NG+}$ AngII; ${ }^{\Phi} p<0.05$ and ${ }^{\Phi \Phi} p<0.01$ vs NG+AngII $+\mathrm{C} 21 ;{ }^{\Psi} p<0.05$ and $\Psi \Psi p<0.01 \mathrm{HG}+$ AngII, ${ }^{\partial} p<0.05$ and ${ }^{\partial \partial} p<0.01$ vs HG + AngII $+\mathrm{C} 21,{ }^{\Omega} p<0.05$ vs HG + AngII + candesartan a
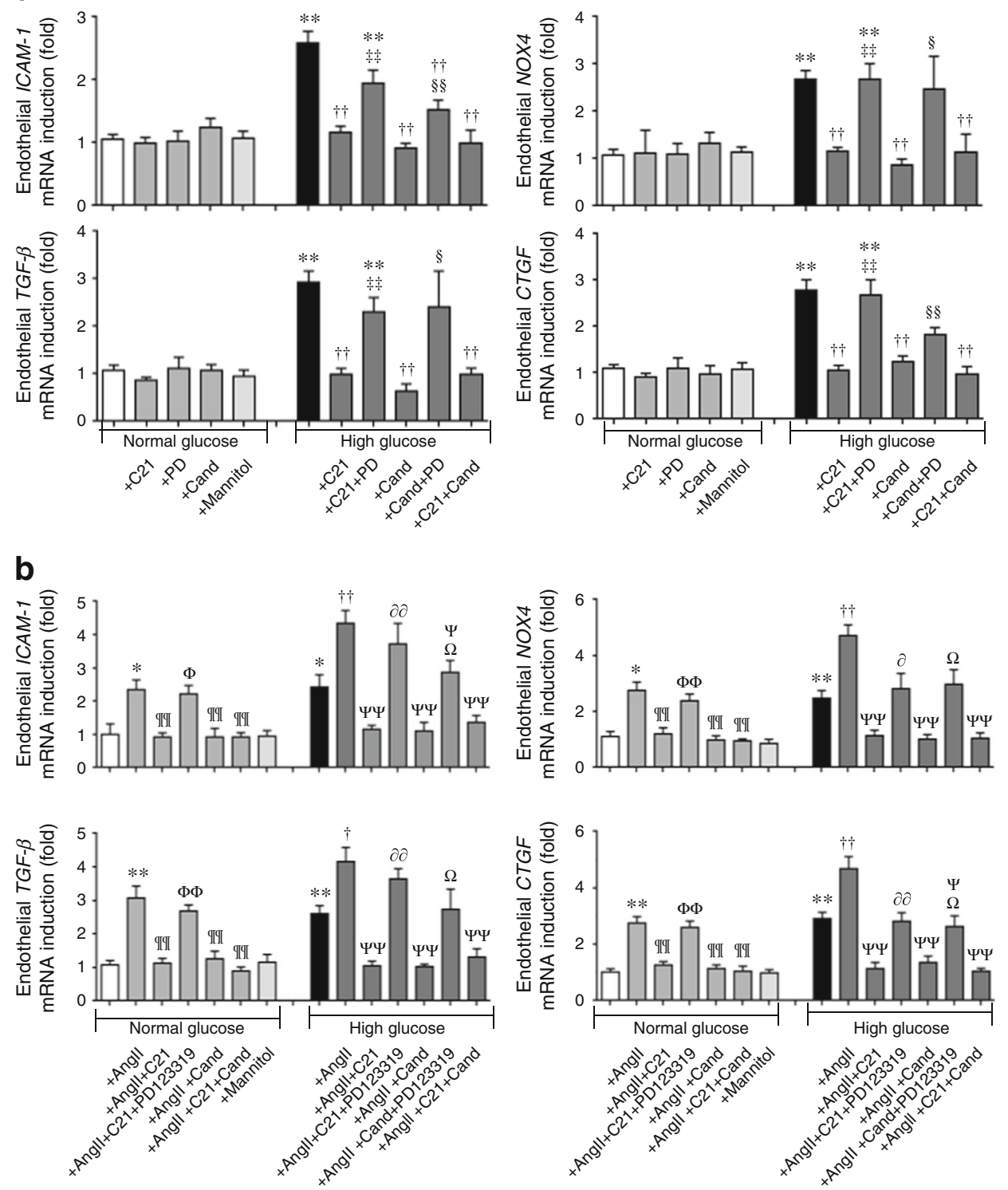

been extensively delineated. This study is the first to exploit the novel non-peptide $\mathrm{AT}_{2} \mathrm{R}$ agonist $\mathrm{C} 21$ in investigating the role of $\mathrm{AT}_{2} \mathrm{Rs}$ in an experimental model of type 1 DAA.

At the in vivo level in mice, $\mathrm{C} 21$ was found to significantly reduce aortic plaque deposition and plaque size, in association with its ability to reduce expression of key mediators of inflammation, oxidative stress and fibrosis in the aorta. Indeed, $\mathrm{C} 21$ at a relatively low dose was found to retard the progression of DAA with similar efficacy to that afforded by the $\mathrm{AT}_{1} \mathrm{R}$ antagonist candesartan, when continuously administered over a 20 week treatment period. Interestingly, co-administration of $\mathrm{C} 21$ and candesartan had no clear-cut additive effect in attenuating DAA when compared with either treatment alone. Nevertheless, these findings support the potential role for $\mathrm{C} 21$ in monotherapy for providing protection against the progression of DAA by inhibiting inflammation, oxidative stress and fibrosis, with the $\mathrm{AT}_{2} \mathrm{R}$ agonist affording similar vasoprotective properties to the $\mathrm{AT}_{1} \mathrm{R}$ antagonist. Consistent with our findings, in an experimental model of myocardial infarction, C21 was demonstrated to improve cardiac function and reduce infarct size with similar efficacy to that observed with candesartan alone [20]. Our additional findings that C21 had no effect in influencing metabolic control or blood pressure in diabetic mice suggest that the beneficial effects seen with this agent do not occur via effects on glycaemic control or via a direct systemic haemodynamic action.

These protective effects of $\mathrm{C} 21$ were further explored in a more mechanistic manner at the in vitro level, in two human cell lines considered to be involved in the development of atherosclerosis - endothelial cells and macrophages [21, 22]. 
Fig. 6 ICAM- $1, N O X 4, T G F-\beta$ and $C T G F$ mRNA levels from THP-1 cells cultured in normal $(5 \mathrm{mmol} / \mathrm{l})$ or high $(25 \mathrm{mmol} / \mathrm{l})$ glucose conditions stimulated in the absence (a) or presence (b) of AngII $(3 \mu \mathrm{mol} / \mathrm{l})$ and treated with either C21 (1 $\mu \mathrm{mol} / \mathrm{l})$, PD123319 $(5 \mu \mathrm{mol} / \mathrm{l})$, candesartan $(10 \mu \mathrm{mol} / \mathrm{l})$, $\mathrm{C} 21+\mathrm{PD} 123319$ or $\mathrm{C} 21+$ candesartan. Cells treated with mannitol $(25 \mathrm{mmol} / \mathrm{l})$ served as osmotic control. Data are shown as the mean \pm SEM; $n=3-10$. mRNA levels were normalised to $18 \mathrm{~S}$ mRNA and reported as relative ratio to the normal glucose group. ${ }^{* *} p<0.01 \mathrm{vs}$ normal glucose (NG); ${ }^{\dagger} p<0.05$ and ${ }^{\dagger \dagger} p<0.01$ vs high glucose (HG); ${ }^{\sharp} p<0.01 \mathrm{vs} \mathrm{HG+C21;}$ ${ }^{\uparrow} p<0.05$ and ${ }^{\uparrow \pi} p<0.01$ vs NG+ AngII; ${ }^{\Phi \Phi} p<0.01 \mathrm{vs} \mathrm{NG}+$ AngII + C21; ${ }^{\Psi}{ }_{p} p<0.01 \mathrm{HG}+$ AngII; ${ }^{\partial \partial} p<0.01$ vs $\mathrm{HG}+$ AngII $+\mathrm{C} 21$ a
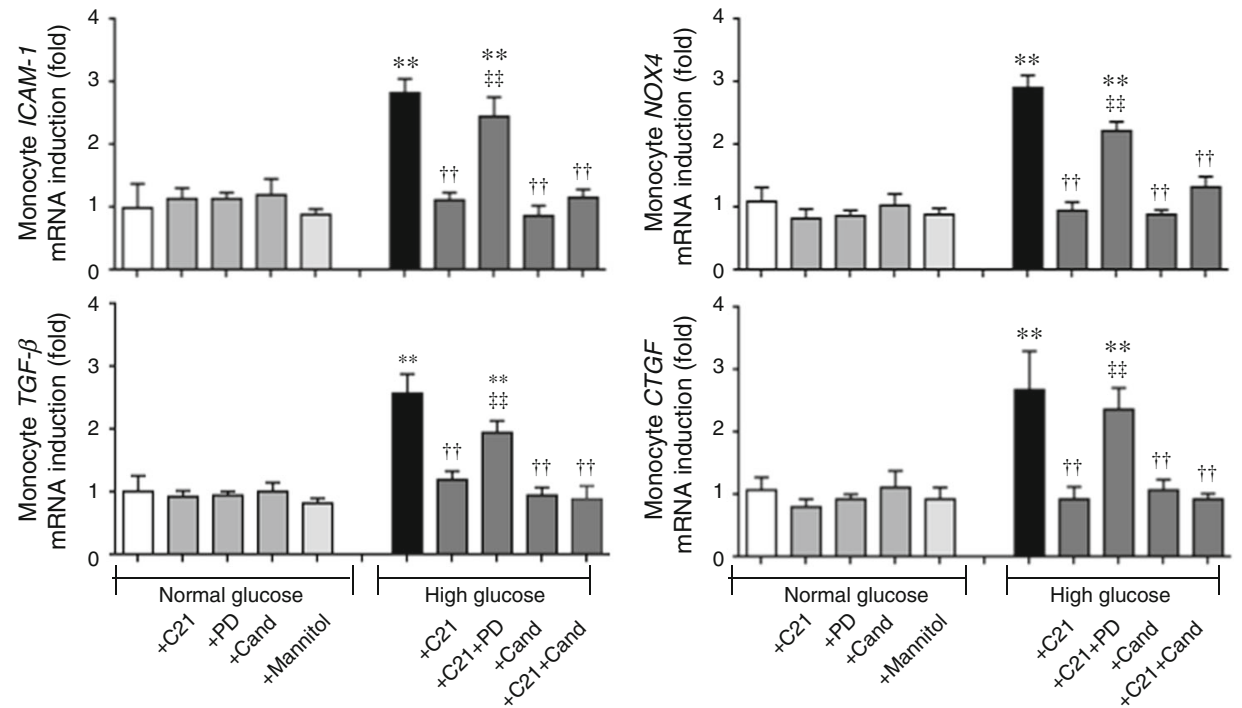

b
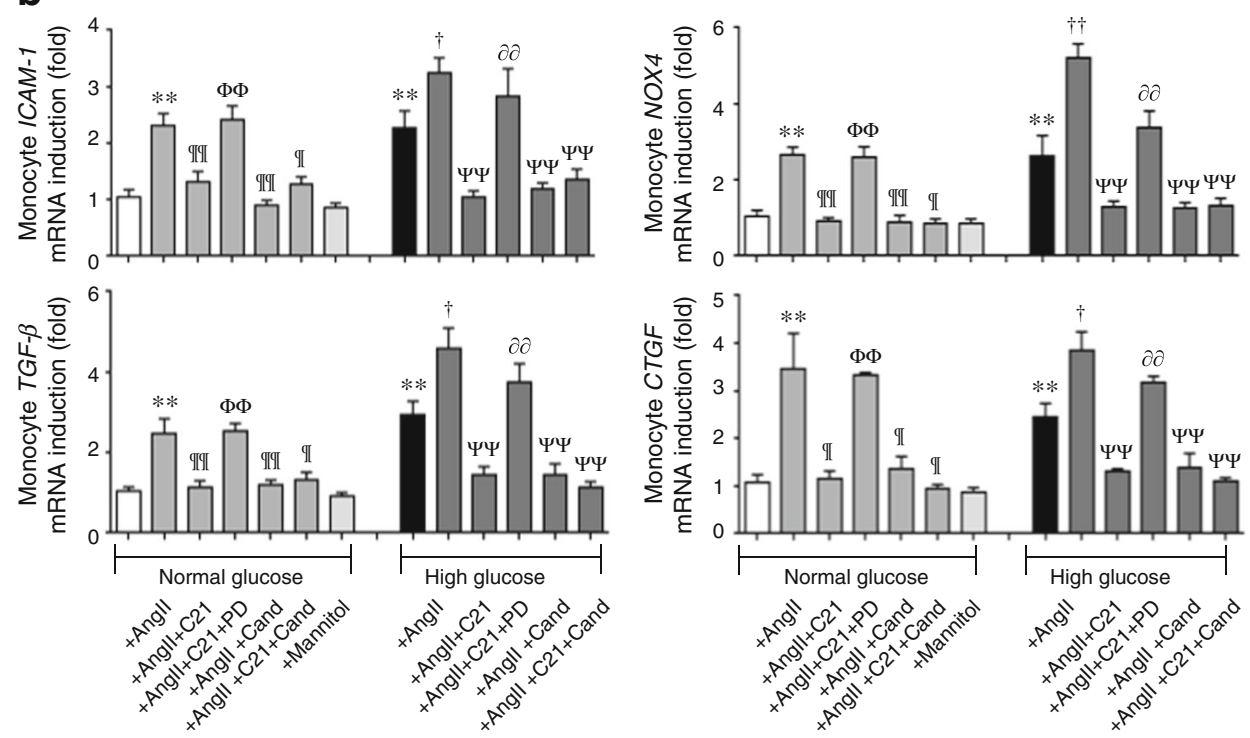

C21 was found to significantly ameliorate markers of oxidative stress, inflammation and fibrosis in both high-glucoseand Ang II-stimulated HAEC and monocytes cultures, with similar efficacy to that of candesartan treatment. Strikingly, these protective effects of $\mathrm{C} 21$ were completely abolished by the $\mathrm{AT}_{2} \mathrm{R}$ antagonist PD123319, thereby confirming the protective actions of $\mathrm{C} 21$ occur via the $\mathrm{AT}_{2} \mathrm{R}$. Nevertheless, with limited understanding and knowledge of the signalling pathways of the $\mathrm{AT}_{2} \mathrm{R}$, it remains to be fully elucidated as to how $\mathrm{C} 21$ confers its benefits in diabetes. Our in vitro and in vivo studies have demonstrated that these effects of $\mathrm{C} 21$ are not dependent on cell type or species and emphasise the central role of $\mathrm{C} 21$ as an anti-inflammatory, antioxidant and antifibrotic agent. This is consistent with previous studies demonstrating the efficacy of $\mathrm{C} 21$ as a reno-protective agent in halting the progression of insulin-deficient diabetic nephropathy $[11,23]$. Thus, these observations strengthen the notion that the $\mathrm{AT}_{2} \mathrm{R}$ agonist $\mathrm{C} 21$ may represent a novel therapy for the treatment of diabetes-associated complications, including both micro- and macrovascular complications.

Given the wide tissue distribution of the $\mathrm{AT}_{2} \mathrm{R}$ [24], $\mathrm{AT}_{2} \mathrm{R}$ activation has been shown to be protective against numerous disease states including renal [25, 26], neuronal [27] and pancreatic injury [28]. However, the role of this receptor in the cardiovascular system still remains poorly understood. Previous studies have variously demonstrated that the $\mathrm{AT}_{2} \mathrm{R}$ could exert a protective [6, 29-33], detrimental [34] or neutral $[35,36]$ role in atherosclerosis. These conflicting reports on the atherosclerotic role of the $\mathrm{AT}_{2} \mathrm{R}$ may suggest that its actions are likely to be dependent on a number of factors. These 
Fig. $7 \mathrm{AT}_{2} \mathrm{R}$ and $\mathrm{AT}_{1} \mathrm{R}$ protein levels from HAEC (a) and THP-1 cells (b) cultured in normal $(5 \mathrm{mmol} / \mathrm{l})$ and high $(25 \mathrm{mmol} / \mathrm{l})$ glucose conditions treated in the absence or presence of $\mathrm{C} 21$ $(1 \mu \mathrm{mol} / \mathrm{l}), \mathrm{C} 21(1 \mu \mathrm{mol} / \mathrm{l})+$ PD123319 (PD) $(5 \mu \mathrm{mol} / \mathrm{l})$, candesartan $(10 \mu \mathrm{mol} / \mathrm{l})$ or $\mathrm{C} 21+$ candesartan. $\alpha$-Tubulin blots were used to demonstrate equivalent loading of protein samples. Data are the mean \pm SEM absorbance (Abs) levels of $\mathrm{AT}_{2} \mathrm{R}$ and $\mathrm{AT}_{1} \mathrm{R}$ and are expressed relative to that of the normal glucose (NG)-treated cells; $n=3$ or 4 . ${ }^{*} p<0.01$ vs NG a
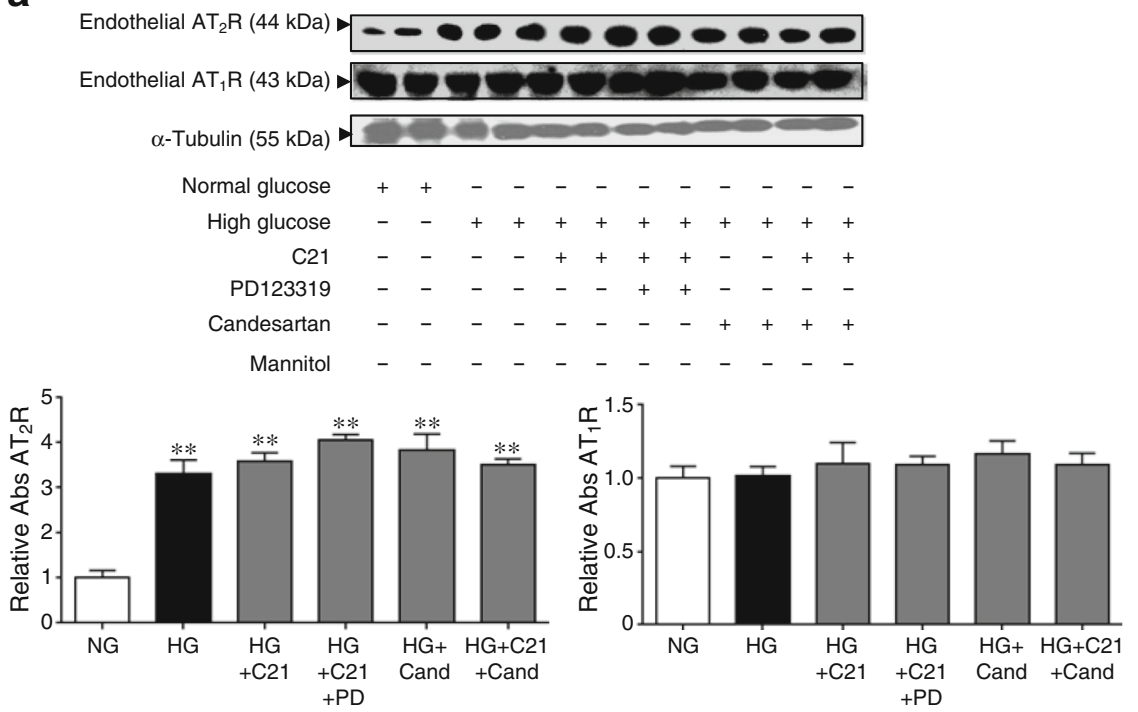

b
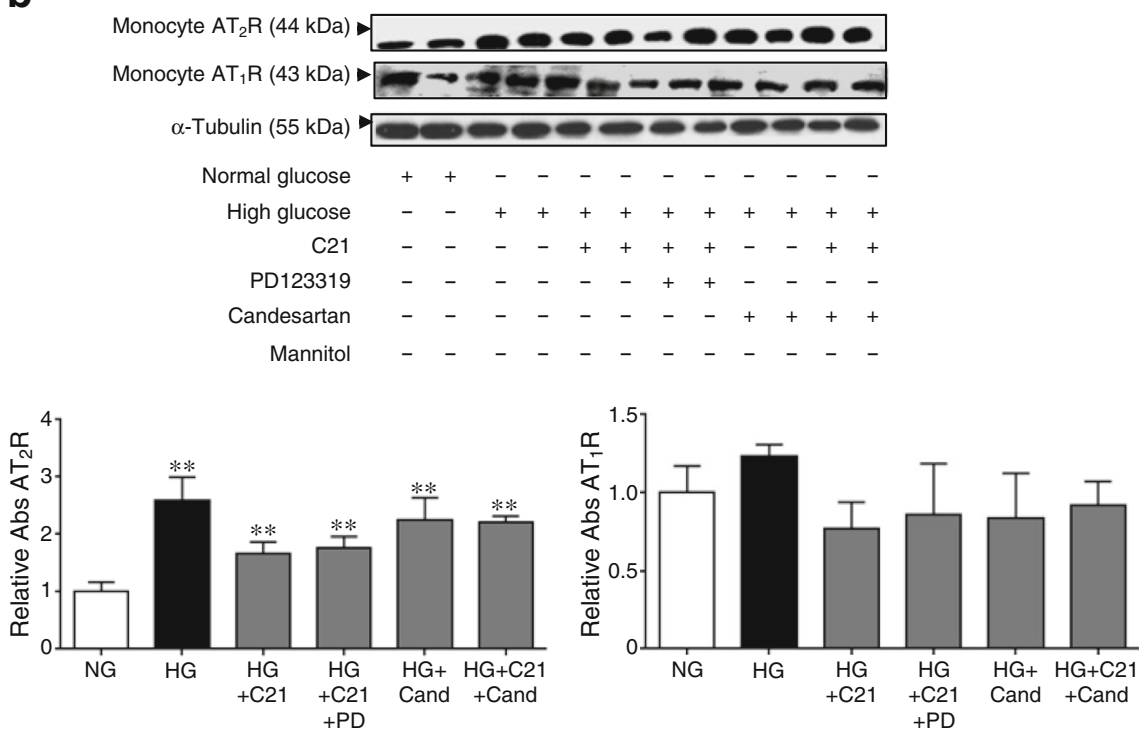

include the severity of the disease, where the efficacy at which $\mathrm{AT}_{2} \mathrm{R}$ mediates its protective effects may be lost in severe chronic conditions [37], the absence or presence of hyperglycaemia [34, 38] and the particular animal strain examined in the study [5]. More recently, the diverse cardiac response associated with the $\mathrm{AT}_{2} \mathrm{R}$ has also been shown to be dependent on the transcription factors with which it interacts. The ability of the $\mathrm{AT}_{2} \mathrm{R}$ to bind and facilitate the translocation of promyelocytic leukaemia zinc finger transcription factor to the nucleus has been shown to be implicated in driving its hypertrophic activity in response to Ang II [39].

Nonetheless, findings in this study have demonstrated that $\mathrm{C} 21$-mediated $\mathrm{AT}_{2} \mathrm{R}$ activation is beneficial against DAA. Consistent with these end-organ protective effects, albeit in the non-diabetic setting, C21 has been shown previously to reduce myocardial fibrosis and vascular injury
[8], improve ventricular function [20] and promote vasodilatation [40] in experimental models of cardiovascular disease. Although both the $\mathrm{AT}_{1} \mathrm{R}$ and $\mathrm{AT}_{2} \mathrm{R}$ were found to be expressed in the human monocytes and aortic endothelial cells used in this study, C21 did not have any marked effects on expression of either receptor. This is consistent with the view that the agonist most likely mediates its actions by influencing post-receptor signalling pathways. Indeed, recent studies have demonstrated that $\mathrm{AT}_{2} \mathrm{R}$ inhibits $\mathrm{AT}_{1} \mathrm{R}$ mediated effects by targeting its downstream effectors, including TGF- $\beta 1$ [41] and NOX [29], as well as its ability to activate vasoconstriction inhibiting factor, an endogenous co-factor of Ang II [42]. Moreover, with previous studies demonstrating that $\mathrm{AT}_{2} \mathrm{R}$ forms a heterodimer receptor complex with $\mathrm{AT}_{1} \mathrm{R}$ to block the signalling and mediated functions of the latter [43], it is possible that some of the 
effects of the $\mathrm{AT}_{2} \mathrm{R}$ agonist involves the complex interaction between the two Ang II receptor subtypes.

Based on our findings that $\mathrm{C} 21$ exhibits similar antiatherogenic efficacy as candesartan and that the effects of candesartan could be inhibited in the presence of the $\mathrm{AT}_{2} \mathrm{R}$ antagonist PD123319, this could indicate that candesartanmediated actions occur at least in part as a result of the unopposed action of the $\mathrm{AT}_{2} \mathrm{R}$. Consistent with these findings are studies, albeit in the non-diabetic setting, where candesartanmediated reduction of infarct size in pigs [44] and inhibition of cardiac remodelling in rats [45] were found to be dependent on $\mathrm{AT}_{2} \mathrm{R}$ activation. Furthermore, it is possible that $\mathrm{AT}_{1} \mathrm{R}$ blockade and $\mathrm{AT}_{2} \mathrm{R}$ agonism are acting through similar signalling pathways. Indeed, several studies have demonstrated that candesartan and C21 inhibit the mitogen-activated protein kinase pathway and signal through a nitric oxide-dependent pathway to mediate their cardioprotective effects [30, 46, 47].

Pilot studies have suggested that $\mathrm{C} 21$ can antagonise the thromboxane receptor (TxR) [48]. Since a TxR antagonist has been shown to reduce atherosclerosis in a similar diabetic apolipoprotein E model [49], one cannot exclude the possibility that the anti-atherosclerotic actions of $\mathrm{C} 21$ could involve the TxR. It remains to be determined whether this is a direct effect of $\mathrm{C} 21$ or involves an indirect action via the $\mathrm{AT}_{2} \mathrm{R}$.

Future studies are warranted to further elucidate interactions between $\mathrm{AT}_{1} \mathrm{R}$ and $\mathrm{AT}_{2} \mathrm{R}$, particularly in cells/organs that co-express the two Ang II receptors, and to identify potential effectors that are involved in mediating the activity of the $\mathrm{AT}_{2} \mathrm{R}$. Our additional finding that $\mathrm{AT}_{2} \mathrm{Rs}$ were upregulated during diabetes could explain why the agonist did not affect aortic function under normal physiological conditions and only displayed its protective effects in DAA. Moreover, recent studies demonstrate that the $\mathrm{AT}_{1} \mathrm{R}$ undergoes desensitisation in response to prolonged exposure to its ligand and that the $\mathrm{AT}_{2} \mathrm{R}$ is unable to recruit $\beta$-arrestins, thereby contributing to the receptor subtype not being desensitised in the same manner as $\mathrm{AT}_{1} \mathrm{R}[50]$. Hence, this allows $\mathrm{C} 21$ to have comparable long-term effects (compared with ARB) in exerting its protective effects, presumably via the $\mathrm{AT}_{2} \mathrm{R}$. Taken together, these findings further highlight the advantage of $\mathrm{C} 21$ as a potential alternative therapy for DAA.

In conclusion, this study has clearly demonstrated that diabetes-related atherosclerosis can be influenced by approaches that target the two angiotensin receptor subtypes. These findings have important clinical significance in providing insight into potential therapeutic agents targeting the RAS that can be developed to halt the progression of DAA. Treatment with $\mathrm{C} 21$ as a monotherapy has been shown to retard the development of aortic atherosclerosis, particularly since it leads to suppression of the underlying oxidative stress, inflammation and fibrosis associated with insulin-deficient DAA. Furthermore, C21 was found to inhibit DAA-induced pathology to an extent similar to that produced by an ARB, suggesting that $\mathrm{C} 21$ may provide an alternative therapy for retarding DAA. Further elucidation of the signalling pathways that are activated by $\mathrm{C} 21$ would represent a crucial step in determining the strengths and limitations of this $\mathrm{AT}_{2} \mathrm{R}$ agonist as a therapeutic agent in treating the vascular complications of both type 1 and type 2 diabetes.

Acknowledgements The authors would like to thank S. Sacca, E. Lastavec and M. Haillay (Baker IDI Heart and Diabetes Institute, Australia) for their technical support. We are grateful to R. Pickering and A. Sharma (Baker IDI Heart and Diabetes Institute, Australia) for providing the monocyte and endothelial cell lines and to A. Ljunggren (Vicore Pharma AB, Göteborg, Sweden) for providing C21.

Funding This study is supported by a National Health \& Medical Research Council of Australia (NHMRC) Project Grant. BSMC is a recipient of a JDRF postdoctoral fellowship. MEC, KAJD and TJA have been supported by NHMRC fellowships.

Duality of interest The authors declare that there is no duality of interest associated with this manuscript. KJD and TJA received Compound 21 from Vicore Pharma AB, Göteborg,, Sweden, as a gift.

Contribution statement All authors contributed to the study concept and design, and the interpretation of the data. BSMC, CK, UMS, TU, MEC, KAJD and TJA conceived and designed the experiments. BSMC, $\mathrm{CK}$ and PK performed the experiments and BSMC, CK, PK, MEC, KAJD and TJA analysed the data. BSMC wrote the paper. The manuscript was edited and reviewed by CK, PK, UMS, TU, MEC, KAJD and TJA. All authors approved the final version of this manuscript. TJA takes full responsibility for the work conducted in this paper.

\section{References}

1. Ma TK, Kam KK, Yan BP, Lam YY (2010) Renin-angiotensinaldosterone system blockade for cardiovascular diseases: current status. Br J Pharmacol 160:1273-1292

2. Jandeleit-Dahm KA, Tikellis C, Reid CM, Johnston CI, Cooper ME (2005) Why blockade of the renin-angiotensin system reduces the incidence of new-onset diabetes. J Hypertens 23:463-473

3. Bosnyak S, Jones ES, Christopoulos A, Aguilar MI, Thomas WG, Widdop RE (2011) Relative affinity of angiotensin peptides and novel ligands at AT1 and AT2 receptors. Clin Sci (Lond) 121: 297-303

4. Mehta PK, Griendling KK (2007) Angiotensin II cell signaling: physiological and pathological effects in the cardiovascular system. Am J Physiol Cell Physiol 292:C82-C97

5. Johren O, Dendorfer A, Dominiak P (2004) Cardiovascular and renal function of angiotensin II type-2 receptors. Cardiovasc Res 62:460-467

6. Sales VL, Sukhova GK, Lopez-Ilasaca MA, Libby P, Dzau VJ, Pratt RE (2005) Angiotensin type 2 receptor is expressed in murine atherosclerotic lesions and modulates lesion evolution. Circulation 112:3328-3336

7. Johansson ME, Fagerberg B, Bergstrom G (2008) Angiotensin type 2 receptor is expressed in human atherosclerotic lesions. J Renin Angiotensin Aldosterone Syst 9:17-21 
8. Rehman A, Leibowitz A, Yamamoto N et al (2012) Angiotensin type 2 receptor agonist compound 21 reduces vascular injury and myocardial fibrosis in stroke-prone spontaneously hypertensive rats. Hypertension 59:291-299

9. Matavelli LC, Huang J, Siragy HM (2011) Angiotensin $\mathrm{AT}_{2}$ receptor stimulation inhibits early renal inflammation in renovascular hypertension. Hypertension 57:308-313

10. Dhande I, Ali Q, Hussain T (2013) Proximal tubule angiotensin $\mathrm{AT}_{2}$ receptors mediate an anti-inflammatory response via interleukin-10: role in renoprotection in obese rats. Hypertension 61:12181226

11. Koulis C, Chow BS, McKelvey $\mathrm{M}$ et al (2015) $\mathrm{AT}_{2} \mathrm{R}$ agonist, compound 21 , is reno-protective against type 1 diabetic nephropathy. Hypertension 65:1073-1081

12. Wan Y, Wallinder C, Plouffe B et al (2004) Design, synthesis, and biological evaluation of the first selective nonpeptide AT2 receptor agonist. J Med Chem 47:5995-6008

13. Hsueh W, Abel ED, Breslow JL et al (2007) Recipes for creating animal models of diabetic cardiovascular disease. Circ Res 100: $1415-1427$

14. Fan Q, Liao J, Kobayashi M et al (2004) Candesartan reduced advanced glycation end-products accumulation and diminished nitro-oxidative stress in type 2 diabetic KK/Ta mice. Nephrol Dial Transplant 19:3012-3020

15. Candido R, Jandeleit-Dahm KA, Cao Z et al (2002) Prevention of accelerated atherosclerosis by angiotensin-converting enzyme inhibition in diabetic apolipoprotein E-deficient mice. Circulation 106: 246-253

16. Koulis C, Kanellakis P, Pickering RJ et al (2014) Role of bonemarrow- and non-bone-marrow-derived receptor for advanced glycation end-products (RAGE) in a mouse model of diabetesassociated atherosclerosis. Clin Sci (Lond) 127:485-497

17. Candido R, Allen TJ, Lassila M et al (2004) Irbesartan but not amlodipine suppresses diabetes-associated atherosclerosis. Circulation 109:1536-1542

18. Li Y, Li XH, Yuan H (2012) Angiotensin II type-2 receptor-specific effects on the cardiovascular system. Cardiovasc Diagn Ther 2:56-62

19. Kljajic ST, Widdop RE, Vinh A et al (2013) Direct $\mathrm{AT}_{2}$ receptor stimulation is athero-protective and stabilizes plaque in apolipoprotein E-deficient mice. Int J Cardiol 169:281-287

20. Kaschina E, Grzesiak A, Li J et al (2008) Angiotensin II type 2 receptor stimulation: a novel option of therapeutic interference with the renin-angiotensin system in myocardial infarction? Circulation 118:2523-2532

21. Jaipersad AS, Lip GY, Silverman S, Shantsila E (2014) The role of monocytes in angiogenesis and atherosclerosis. J Am Coll Cardiol 63:1-11

22. Tabas I, Garcia-Cardena G, Owens GK (2015) Recent insights into the cellular biology of atherosclerosis. J Cell Biol 209:13-22

23. Matavelli LC, Zatz R, Siragy HM (2015) A nonpeptide angiotensin II type 2 receptor agonist prevents renal inflammation in early diabetes. J Cardiovasc Pharmacol 65:371-376

24. de Gasparo M, Catt KJ, Inagami T, Wright JW, Unger T (2000) International union of pharmacology. XXIII. The angiotensin II receptors. Pharmacol Rev 52:415-472

25. Ma J, Nishimura H, Fogo A, Kon V, Inagami T, Ichikawa I (1998) Accelerated fibrosis and collagen deposition develop in the renal interstitium of angiotensin type 2 receptor null mutant mice during ureteral obstruction. Kidney Int 53:937-944

26. Chang SY, Chen YW, Chenier I, Tran Sle M, Zhang SL (2011) Angiotensin II type II receptor deficiency accelerates the development of nephropathy in type I diabetes via oxidative stress and ACE2. Exp Diabetes Res 2011:521076

27. Li J, Culman J, Hortnagl H et al (2005) Angiotensin AT2 receptor protects against cerebral ischemia-induced neuronal injury. FASEB J 19:617-619
28. Ulmasov B, Xu Z, Tetri LH, Inagami T, Neuschwander-Tetri BA (2009) Protective role of angiotensin II type 2 receptor signaling in a mouse model of pancreatic fibrosis. Am J Physiol Gastrointest Liver Physiol 296:G284-G294

29. Iwai M, Chen R, Li Z, Shiuchi T, Suzuki J et al (2005) Deletion of angiotensin II type 2 receptor exaggerated atherosclerosis in apolipoprotein E-null mice. Circulation 112:1636-1643

30. Takata H, Yamada H, Kawahito H et al (2015) Vascular angiotensin II type 2 receptor attenuates atherosclerosis via a kinin/NO-dependent mechanism. J Renin Angiotensin Aldosterone Syst 16:311-320

31. Daugherty A, Manning MW, Cassis LA (2001) Antagonism of AT2 receptors augments angiotensin II-induced abdominal aortic aneurysms and atherosclerosis. Br J Pharmacol 134:865-870

32. Hu C, Dandapat A, Chen J, Liu Y, Hermonat PL, Carey RM, Mehta JL (2008) Over-expression of angiotensin II type 2 receptor (agtr2) reduces atherogenesis and modulates LOX-1, endothelial nitric oxide synthase and heme-oxygenase-1 expression. Atherosclerosis 199:288-294

33. Kato T, Kawahito H, Kishida S et al (2015) Bone marrow angiotensin $\mathrm{AT}_{2}$ receptor deficiency aggravates atherosclerosis development by eliminating macrophage liver $\mathrm{X}$ receptor-mediated antiatherogenic actions. J Renin Angiotensin Aldosterone Syst 16: 936-946

34. Koitka A, Cao Z, Koh P et al (2010) Angiotensin II subtype 2 receptor blockade and deficiency attenuate the development of atherosclerosis in an apolipoprotein E-deficient mouse model of diabetes. Diabetologia 53:584-592

35. Daugherty A, Rateri DL, Howatt DA, Charnigo R, Cassis LA (2013) PD123319 augments angiotensin II-induced abdominal aortic aneurysms through an AT2 receptor-independent mechanism. PLoS One 8:e61849

36. Daugherty A, Rateri DL, Lu H, Inagami T, Cassis LA (2004) Hypercholesterolemia stimulates angiotensin peptide synthesis and contributes to atherosclerosis through the $\mathrm{AT}_{1 \mathrm{~A}}$ receptor. Circulation 110:3849-3857

37. Oishi Y, Ozono R, Yano Y et al (2003) Cardioprotective role of $\mathrm{AT}_{2}$ receptor in postinfarction left ventricular remodeling. Hypertension 41:814-818

38. Falcon BL, Stewart JM, Bourassa E et al (2004) Angiotensin II type 2 receptor gene transfer elicits cardioprotective effects in an angiotensin II infusion rat model of hypertension. Physiol Genomics 19: 255-261

39. Wang N, Frank GD, Ding R et al (2012) Promyelocytic leukemia zinc finger protein activates GATA4 transcription and mediates cardiac hypertrophic signaling from angiotensin II receptor 2. PLoS One 7:e35632

40. Bosnyak S, Welungoda IK, Hallberg A, Alterman M, Widdop RE, Jones ES (2010) Stimulation of angiotensin $\mathrm{AT}_{2}$ receptors by the non-peptide agonist, Compound 21, evokes vasodepressor effects in conscious spontaneously hypertensive rats. Br J Pharmacol 159: 709-716

41. Chow BS, Kocan M, Bosnyak S et al (2014) Relaxin requires the angiotensin II type 2 receptor to abrogate renal interstitial fibrosis. Kidney Int 86:75-85

42. Salem S, Jankowski V, Asare Y et al (2015) Identification of the vasoconstriction-inhibiting factor (VIF), a potent endogenous cofactor of angiotensin II Acting on the angiotensin II type 2 receptor. Circulation 131:1426-1434

43. AbdAlla S, Lother H, Abdel-tawab AM, Quitterer U (2001) The angiotensin II $\mathrm{AT}_{2}$ receptor is an $\mathrm{AT}_{1}$ receptor antagonist. J Biol Chem 276:39721-39726

44. Jalowy A, Schulz R, Dorge H, Behrends M, Heusch G (1998) Infarct size reduction by AT1-receptor blockade through a signal cascade of $\mathrm{AT}_{2}$-receptor activation, bradykinin and prostaglandins in pigs. J Am Coll Cardiol 32:1787-1796 
45. Jones ES, Black MJ, Widdop RE (2004) Angiotensin $\mathrm{AT}_{2}$ receptor contributes to cardiovascular remodelling of aged rats during chronic $\mathrm{AT}_{1}$ receptor blockade. J Mol Cell Cardiol 37:1023-1030

46. Barauna VG, Mantuan PR, Magalhaes FC, Campos LC, Krieger JE (2013) AT1 receptor blocker potentiates shear-stress induced nitric oxide production via modulation of eNOS phosphorylation of residues $\operatorname{Thr}(495)$ and Ser(1177). Biochem Biophys Res Commun 441:713-719

47. Zhang GX, Kimura S, Murao K et al (2010) Effects of angiotensin type I receptor blockade on the cardiac Raf/MEK/ERK cascade activated via adrenergic receptors. J Pharmacol Sci 113:224-233
48. Zuccollo A, Shi C, Mastroianni R et al (2005) The thromboxane A2 receptor antagonist S18886 prevents enhanced atherogenesis caused by diabetes mellitus. Circulation 112:3001-3008

49. Steckelings UM, Fredgart M, Leurgans T et al (2015) Abstract P143: The angiotensin $\mathrm{AT}_{2}$ receptor agonist Compound 21 is a low affinity thromboxane $\mathrm{A}_{2}$ receptor antagonist. Hypertension 66:AP143

50. Porrello ER, Pfleger KD, Seeber RM et al (2011) Heteromerization of angiotensin receptors changes trafficking and arrestin recruitment profiles. Cell Signal 23:1767-1776 